\title{
Re-augmentation of the Axilla Using a Turn-Over Flap - a New Approach for the Surgical Treatment of Secondary Lymphedema After Breast Cancer
}

\author{
Einsatz eines Wendelappens zur Wiederherstellung des \\ Volumens im Achselbereich - ein neuer Behandlungsansatz \\ für die operative Versorgung von sekundären Lymphödemen \\ nach Brustkrebstherapie
}

\section{(이 (1) (요 $\ominus$}

Authors

Mario Marx ${ }^{1,2}$, Michael Geßner ${ }^{1}$, Alexander Florek ${ }^{1}$, Susanne Morgenstern ${ }^{1}$, Stefan Passin ${ }^{1}$, Sara Y. Brucker ${ }^{2}$, Diethelm Wallwiener ${ }^{2}$, Markus Hahn²

Affiliations

1 Elbland Hospital Radebeul, Department of Plastic, Reconstructive and Breast Surgery, Radebeul, Germany

2 Department for Women's Health, University of Tübingen, Tübingen, Germany

Key words

lymphedema, breast cancer, lymph node transplantation, axillary node, breast cancer-related lymphedema

\section{Schlüsselwörter}

Lymphödem, Mammakarzinom, Lymphknotentransplantation, Achsellymphknoten, brustkrebsassoziiertes Lymphödem

received 13.9.2019

revised $\quad 18.11 .2019$

accepted 18.11.2019

Bibliography

DOI https://doi.org/10.1055/a-1063-6310

Geburtsh Frauenheilk 2020; 80: 526-531 @ Georg Thieme Verlag KG Stuttgart · New York | ISSN 0016-5751

Correspondence

Prof. Dr. Markus Hahn

Department for Women's Health, University of Tuebingen

Calwerstraße 7, 72076 Tübingen, Germany

markus.hahn@med.uni-tuebingen.de

\section{ABSTRACT}

Introduction Scarring and volume reduction of the axillary space resulting in persistent lymphedema is a side effect of axillary treatment in breast cancer patients. The aim of this paper is to describe the reduction of lymphedema achieved with a turnover flap.

Materials and Methods Between October 2016 and May 2018 , five patients with grade 2 lymphedema following breast cancer therapy underwent reconstructive surgery with a turnover flap. Complete excision of the symptomatic axillary scar tissue followed by re-augmentation using a turnover flap was performed. Subsequently, all patients underwent breast reconstruction using a distant flap reconnected to the thoracodorsal vessels. The circumference of both arms, quality of life and pain were measured before and after surgery.

Results An average reduction in pain in the ipsilateral arm from 6 to 1 on the numerical scale as well as an improvement in quality of life (2.8 vs. 7.0) was observed. A decrease in lymphedema especially in the upper arm was identified. No complications such as secondary bleeding, infections or flap loss were observed.

Conclusion Complete removal of the axillary scar tissue after breast cancer treatment and re-augmentation of the axilla with a turnover flap results in a reduction in ipsilateral lymphedema and an improvement in pain and quality of life. We interpret these findings as a result of the physiological re-alignment of the lymphatic vessels combined with a lymph nodecontaining local transposition flap. Therefore, re-augmentation with a turnover flap could be an effective non-microsurgical alternative to lymph node transplantation. 


\section{ZUSAMMENFASSUNG}

Einleitung Vernarbungen und die Reduzierung des Volumens im Achselbereich können zu einem anhaltenden Lymphödem führen und zählen zu den häufigsten Nebenwirkungen nach einer Brustkrebstherapie im Achselbereich. Es wird hier eine Technik zur Reduzierung von Lymphödemen mithilfe eines Rotationslappens vorgestellt.

Material und Methoden Zwischen Oktober 2016 und Mai 2018 haben 5 Patientinnen mit einem Stadium-2-Lymphödem infolge früherer Brustkrebstherapien sich einer operativen Rekonstruktion mit Rotationslappenplastik unterzogen. In einem ersten Schritt wurde das symptomatische Narbengewebe im Achselbereich vollständig herausgeschnitten. Hiernach erfolgt eine Wiederherstellung des Volumens im Achselbereich mithilfe eines Wendelappens. Danach wurde bei allen Patientinnen eine Brustrekonstruktion mit einem mit den thorakodorsalen Gefäßen verbundenen Fernlappen durchgeführt. Der Umfang beider Arme, die Lebensqualität und die Schmerzen wurden vor und nach der Operation gemessen.
Ergebnisse Im Durchschnitt sanken die Schmerzen im ipsilateralen Arm von 6 auf 1 auf der numerischen Schmerzskala, und die Lebensqualität verbesserte sich merklich $(2,8$ vs. 7,0$)$. Das Lymphödem wurde deutlich kleiner, vor allem im Oberarm. Komplikationen, wie z. B. sekundäre Blutungen, Infektionen oder Lappenverlust, sind nicht aufgetreten.

Schlussfolgerung Eine vollständige Entfernung der nach Brustkrebsbehandlungen entstandenen Vernarbungen im Achselbereich und eine Wiederherstellung des Achselbereichvolumens mithilfe eines Wendelappens führte zu einer Minderung des ipsilateralen Lymphödems und zu einer Verbesserung der Schmerzen und der Lebensqualität. Wir deuten dieses Outcome als Ergebnis der physiologischen Ausrichtung der Lymphgefäße mit einem in einem Transpositionslappen enthaltenen Lymphknoten. Eine Wiederherstellung des Volumens im Achselbereich mithilfe eines Wendelappens könnten eine wirksame Alternative zur Lymphknotentransplantation darstellen.

\section{Introduction}

Lymphedema of the upper limb is one of the main complications after surgical treatment and radiotherapy of breast cancer [1]. Clinical experience and current studies show that of 69000 primary breast cancer patients per year in Germany, the incidence of patients with lymphedema who require treatment is $16.6 \%$, thus equating to approximately 11500 patients [2]. This disorder in lymphatic drainage can result in a significant reduction in quality of life and is caused mainly by surgical lymphadenectomy and/or radiotherapy [2,3]. The incidence of lymphedema 12-24 months after breast cancer treatment with axillary lymph node removal is $19.9 \%$ [2]. Patients who have undergone axillary dissection and radiation are even more likely to develop lymphedema [3-5]. The estimated risk of breast cancer-related lymphedema has been reduced to $6-10 \%$ following the introduction of sentinel lymph node biopsy [7]. However, complications can arise not only due to treatment-related risk factors, but also due to patient-related factors, such as obesity and hypertension $[5,6,8,9]$. Left untreated, lymphedema often results in disease progression with increasing symptoms. As reconstructive surgery is the first-line surgical therapy in most patients, there have been numerous advances, especially in this area. Baumeister performed the first microsurgical lymph vessel transplantation in 1981 [10]. The first report on free lymph node transplantation appeared in 2000 in a publication by Corinne Becker [11]. The current German guideline favors lymph vessel reconstruction in patients with progressive disease in whom the conservative therapeutic options have been exhausted [12].

Based on experience with more than 2000 breast reconstructions using a free flap technique with the anastomosis performed at the thoracodorsal vessels, we observed an astonishing effect in the ipsilateral upper limbs. Many patients reported a reduction in the ipsilateral lymphedema. The same effect was observed with scar tissue removal for the treatment of symptomatic axillary scarring after breast cancer surgery or radiotherapy. Here, we

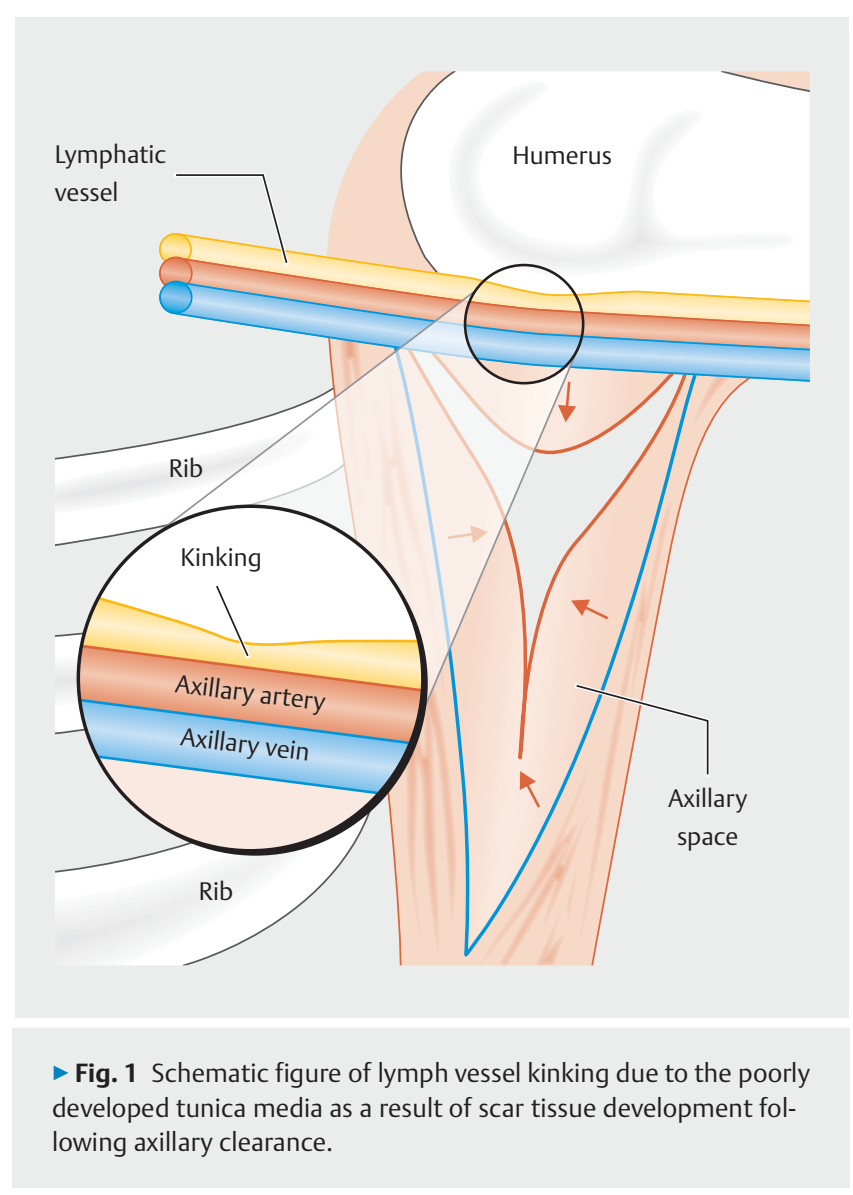

augmented the resulting space with a local flap in an attempt to avoid recurrent scarring. Consequently, complete excision of the scar tissue combined with re-augmentation had an effect which we interpret as a result of the re-alignment of the persistently kinked lymphatic vessels ( $\boldsymbol{\text { Fig. }}$ 1) and the use of a lymph node- 
containing local flap (turnover flap). The aim of this paper is to describe this surgical technique and the observed reduction in symptomatic lymphedema following the complete removal of axillary scar tissue and re-augmentation with a local turnover flap in five representative cases.

\section{Materials and Methods}

This retrospective analysis involves five patients who underwent breast reconstruction combined with complete scar tissue excision and re-augmentation of the axilla using a turnover flap ( $\vee$ Table 1) after breast cancer treatment and persistent lymphedema grade 2 following conservative treatment. All data in this retrospective analysis were anonymized. The local ethics committee was informed about the retrospective analysis. All patients provided written consent. Prior to surgery, the patients had gone through at least six months of conservative treatment, which led to either no improvement or even to progression of lymphedema. In addition to re-augmentation of the axilla with a turnover flap, we planned breast reconstruction using a free perforator flap. Patients were photodocumented pre- and postoperatively ( $\vee$ Fig. 2), standardized circumferential measurements of both arms were carried out, and patients answered a validated questionnaire on quality of life for lymphedema (LYMQOL) [13]. Scoring was based on 20 questions in 4 domains: function (Q1-3), appearance (Q48), symptoms (Q9-14), and mood (Q15-20). Each item score

- Table 1 Summary of demographic data of our five patients as well as evaluation of pre- and postoperative pain and quality of life.

\begin{tabular}{|c|c|c|c|c|c|c|}
\hline \multicolumn{2}{|l|}{ Patient } & 1 & 2 & 3 & 4 & 5 \\
\hline \multicolumn{2}{|l|}{ Age } & 59 & 50 & 43 & 59 & 48 \\
\hline \multicolumn{2}{|l|}{$\mathrm{BMI}\left(\mathrm{kg} / \mathrm{m}^{2}\right)$} & 24.7 & 36.5 & 25.9 & 31.8 & 24.22 \\
\hline \multicolumn{2}{|l|}{ Lymphedema grade } & Grade 2 & Grade 2 & Grade 2 & Grade 2 & Grade 2 \\
\hline \multicolumn{2}{|l|}{ Previous treatment } & $\begin{array}{l}\text { Mastectomy and } \\
\text { axillary dissection }\end{array}$ & $\begin{array}{l}\text { Mastectomy and } \\
\text { axillary dissection }\end{array}$ & $\begin{array}{l}\text { SSM and sec. } \\
\text { axillary dissection }\end{array}$ & $\begin{array}{l}\text { BCT and axillary } \\
\text { dissection, SSM } \\
\text { (recurrence } \\
\text { disease) }\end{array}$ & $\begin{array}{l}\text { SSM and axillary } \\
\text { dissection }\end{array}$ \\
\hline \multicolumn{2}{|l|}{ Date of first diagnosis } & $01 / 2008$ & $11 / 2012$ & $08 / 2014$ & $\begin{array}{l}1992 \\
09 / 2015\end{array}$ & $11 / 2013$ \\
\hline \multicolumn{2}{|l|}{ TNM-Staging } & $\begin{array}{l}\text { pT3 pN0 } \\
\text { (0/21 LK) } \\
\text { M0 L1 G3 R1 }\end{array}$ & $\begin{array}{l}\text { pT2 pN1a } \\
\text { (2/20 LK) } \\
\text { M0 V0 L1 G2 R0 }\end{array}$ & $\begin{array}{l}\text { ypT0 ypN1a } \\
(1 / 7 \text { LK) } \\
\text { cM0 yL0 yV0 } \\
\text { G3 R0 }\end{array}$ & $\begin{array}{l}\text { pT2 pN0 } \\
\text { (0/8 LK) M0, } \\
\text { rpT1b pN0 (0/4) } \\
\text { M0 L0 V0 G2 R0 }\end{array}$ & $\begin{array}{l}\text { pT1c pN2 } \\
\text { (6/10 LK) } \\
\text { M0 V0 L1 G2 R0 }\end{array}$ \\
\hline \multicolumn{2}{|l|}{ Receptor status } & $\begin{array}{l}\text { ER: IRS = } 12 \\
\text { PR: IRS = } 4 \\
\text { Her-2/neu: } \\
\text { negative }\end{array}$ & $\begin{array}{l}\text { ER: IRS = } 12 \\
\text { PR: IRS = } 12 \\
\text { Her-2/neu: } \\
\text { negative }\end{array}$ & $\begin{array}{l}\text { ER: IRS = } 6 \\
\text { PR: IRS = 9 } \\
\text { Her-2/neu: } \\
\text { positive }\end{array}$ & $\begin{array}{l}\text { ER: IRS = } 2 \\
\text { PR: IRS = } 0 \\
\text { Her-2/neu: } \\
\text { negative }\end{array}$ & $\begin{array}{l}\text { ER: IRS = } 9 \\
\text { PR: IRS = } 6 \\
\text { Her-2/neu: } \\
\text { negative }\end{array}$ \\
\hline \multicolumn{2}{|l|}{ Systemic therapy } & $\begin{array}{l}\text { Adjuvant ( } 3 \times \\
\text { FEC, } 3 \times \text { docetax- } \\
\text { el), endocrine } \\
\text { therapy: tamoxi- } \\
\text { fen }\end{array}$ & $\begin{array}{l}\text { Adjuvant } \\
(6 \times \mathrm{TAC}) \text {, endo- } \\
\text { crine therapy: } \\
\text { tamoxifen }\end{array}$ & $\begin{array}{l}\text { Neoadjuvant } \\
(3 \times \text { FEC, } 3 \times \text { do- } \\
\text { cetaxel) and } \\
\text { trastuzumab, } \\
\text { endocrine ther- } \\
\text { apy: tamoxifen }\end{array}$ & $\begin{array}{l}\text { Adjuvant }(4 \times \mathrm{EC} \text {, } \\
12 \times \text { Taxol), } \\
\text { endocrine ther- } \\
\text { apy: tamoxifen }\end{array}$ & $\begin{array}{l}\text { Adjuvant ( } 4 \times \mathrm{EC} \text {, } \\
12 \times \text { Taxol), } \\
\text { endocrine ther- } \\
\text { apy: tamoxifen }\end{array}$ \\
\hline \multicolumn{2}{|l|}{ Radiotherapy } & $\begin{array}{l}\text { Thoracic wall and } \\
\text { axilla + supracla- } \\
\text { vicular ( } 68,4 \mathrm{~Gy})\end{array}$ & $\begin{array}{l}\text { Thoracic wall and } \\
\text { axilla (50,4 Gy) }\end{array}$ & $\begin{array}{l}\text { Thoracic wall and } \\
\text { axilla }\end{array}$ & $\begin{array}{l}\text { whole-breast } \\
\text { irradiation with } \\
\text { boost }\end{array}$ & $\begin{array}{l}\text { Thoracic wall and } \\
\text { axilla + supracla- } \\
\text { vicular ( } 50,4 \mathrm{~Gy})\end{array}$ \\
\hline \multicolumn{2}{|l|}{ Date of turn-over flap } & $05 / 2016$ & $08 / 2016$ & $11 / 2016$ & 09/2017 & $11 / 2017$ \\
\hline \multirow[t]{2}{*}{ Pain score (NASO-10) } & Pre-op. & 8 & 5 & 8 & 2 & 7 \\
\hline & Post-op. & 1 & 0 & 3 & 1 & 0 \\
\hline \multirow{2}{*}{$\begin{array}{l}\text { Lymphedema } \\
\text { treatment }\end{array}$} & Pre-op. & Yes & Yes & Yes & Yes & Yes \\
\hline & Post-op. & No & limited time only & limited time only & No & No \\
\hline \multirow[t]{2}{*}{ LYMQOL-score } & Pre-op. & 63 & 64 & 74 & 47 & 48 \\
\hline & Post-op. & 49 & 41 & 64 & 44 & 30 \\
\hline \multirow{2}{*}{$\begin{array}{l}\text { Quality of life ( } 0=\text { very } \\
\text { poor to } 10=\text { very good })\end{array}$} & Pre-op. & 2 & 3 & 2 & 3 & 4 \\
\hline & Post op. & 7 & 8 & 5 & 7 & 8 \\
\hline \multicolumn{7}{|c|}{$\begin{array}{l}\text { LYMQOL-Score: the four domains are: function (Q1-3), appearance (Q4-8), symptoms (Q9-14) and mood (Q15-20). } \\
\text { Each item score ranges from } 1 \text { (not at all) to } 4 \text { (a lot). }\end{array}$} \\
\hline \multicolumn{7}{|c|}{ BCT: breast conserving therapy, SSM: Skin sparing mastectomy, ER: Estrogen receptor, PR: Progesteron receptor } \\
\hline
\end{tabular}




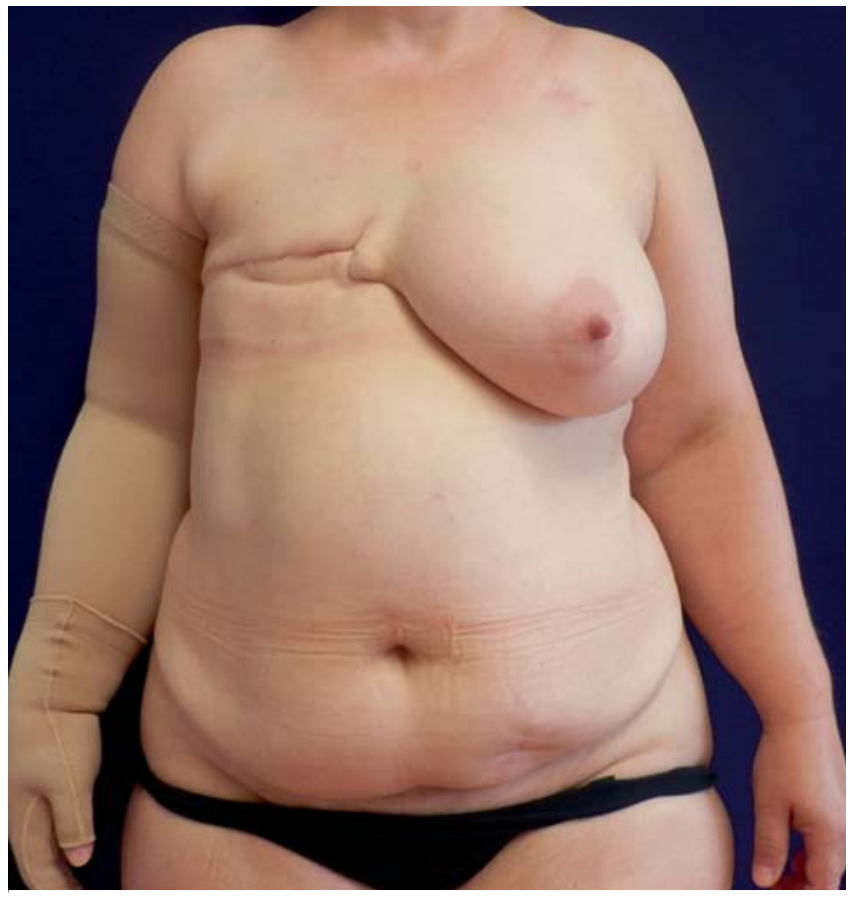

- Fig. 2 Preoperative site.

ranged from 1 (not at all) to 4 (a lot). Pain history was documented using a numerical rating scale from 0 (no pain) to 10 (strongest pain). A follow-up took place at week 1 and 6 as well as 6 months postoperatively. Measurements were always taken at the same time of day (2-hour range) to avoid daytime variations in the lymphedema.

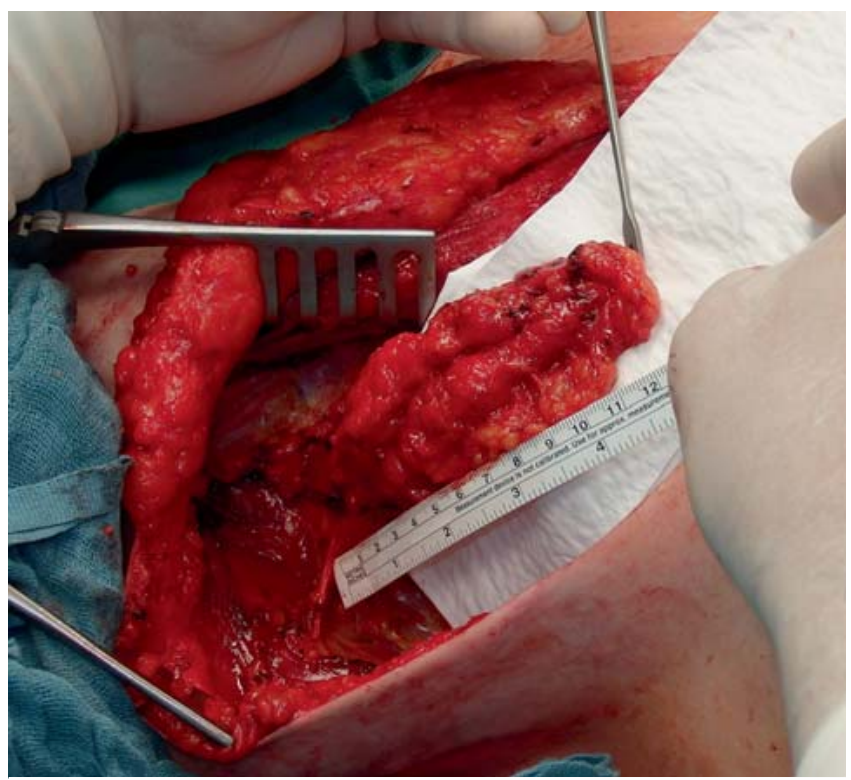

- Fig. 3 Incised turnover flap before transposition into the axillary region for re-augmentation of the volume deficit following scar tissue excision.

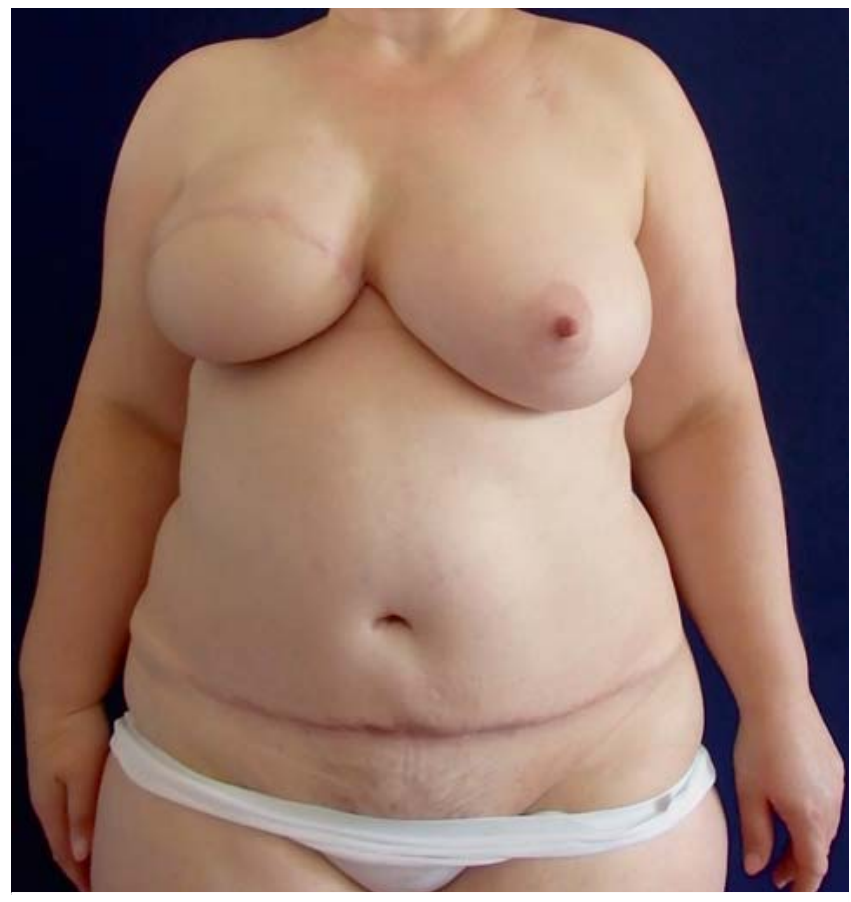

- Fig. 4 Surgical site 6 weeks postoperatively.

\section{Surgical Technique}

The main strategy of this technique is the complete excision of scar tissue in the axilla resulting from previous surgery and radiotherapy. Once the compromising scar tissue has been removed in full, an axillary volume deficit arises. The thoracodorsal and thoracolateral vascular structures and nerves are fully visualized during the preparation and serve to connect the perforator flap. Intraoperative ultrasound (12 MHz, B-mode and color Doppler) and surgical loupes are used to visualize the lateral thoracic artery and vein with adherent lymph node-containing fatty tissue distal to the axillary vein on the lateral margin of the pectoralis major muscle. The size of the lymph node-fat conglomerate should be such that it fills the existing volume deficit ( $\vee$ Fig. 3 ). The adipofascial island flap is then incised distally together with the fascia of the serratus anterior muscle. After clip occlusion of the vessels distal to the turnover flap, the lymph node-fat conglomerate is rotated to the axillary vein through the space created by the scar tissue excision. This results in compensation of the previously incurred tissue loss by adequately vascularized lymphatic and adipose tissue. Autologous breast reconstruction was subsequently performed using a deep inferior epigastric perforator flap ( Fig. 4).

\section{Results}

A turnover flap procedure with a full follow-up was performed in five patients ( $\triangleright$ Table $\mathbf{1}$ ).

All patients were diagnosed preoperatively with second-degree lymphedema, with painful movement restrictions caused by an increase in the circumference of the affected arm and a consequently 
reduced quality of life. All patients had gone through at least 6 months of conservative treatment prior to the surgery, but the symptoms continued to progress. Complete measurements and questionnaires were available from three patients. $>$ Fig. 5 demonstrates the presence of lymphatic tissue and perfusion visualized through a preoperative injection of indocyanine green in the lateral thoracic wall and the patient's hand using an infrared camera.

\section{Pain}

Prior to the surgery, the patients reported an average pain level of $6(2-8)$ on a numerical analogue scale. Six weeks after the surgical procedure, a reduction in pain in the affected limb was reported in all patients. On average, the pain score was $1(0-3)$, while two patients reported being completely pain-free.

\section{Conservative treatment}

Six weeks after the procedure, three of the five patients needed no further conservative treatment for lymphedema. The other two patients were able to extend the interval between their conservative treatment sessions. None of the patients had to wear a compression sleeve.

\section{Circumference of the ipsilateral arm}

Measurements of the arm were performed at the wrist, the cubital fossa as well as $5 \mathrm{~cm}$ proximally and distally of the elbow and the upper arm near the axilla. The greatest circumferential reduction of lymphedema after 6 weeks was observed in the upper arm with an average reduction of 3.57 vs. $1.1 \mathrm{~cm}$ in the contralateral arm, followed by the site $5 \mathrm{~cm}$ proximally of the cubital fossa (1.1 vs. $1.5 \mathrm{~cm})$ and the wrist $(1.0$ vs. $0.6 \mathrm{~cm})$.

\section{Quality of life}

Postoperatively, the overall quality of life improved by 4.2 points (2.8 vs. 7 ) on a numerical analogue scale.

The LYMQOL questionnaire also describes an improvement in lymphedema associated with quality of life. On average, the preoperative score in our patients was 59.2 (47-74). Postoperatively, the average pain score was reduced by 13.6 points to 45.6 (30$64)$, thus equating an improvement in quality of life.

\section{Discussion}

Lymphedema of the upper limb following axillary dissection with or without radiotherapy is a well-known complication in breast cancer patients [14]. If conservative treatment fails, surgical therapy is an option for these patients. According to the International Society of Lymphology surgical procedures provide the closest chance for a cure of lymph flow disorders [15]. Options with good long-term results are lymphatic-venous anastomoses (LVA) and vascularized lymph node transplantation (VLNT) [16]. LVA is the most common procedure and aims to bypass the obstructed area by creating multiple anastomoses between lymphatic and venous vessels to divert lymph fluid into the venous system distal to the obstruction. Due to the pressure gradient, congested fluid is drawn through the anastomosis. The efficacy of this technique has been demonstrated only in early-stage lymphedema, because tissue fibrosis in more advanced stages results in dysfunctional

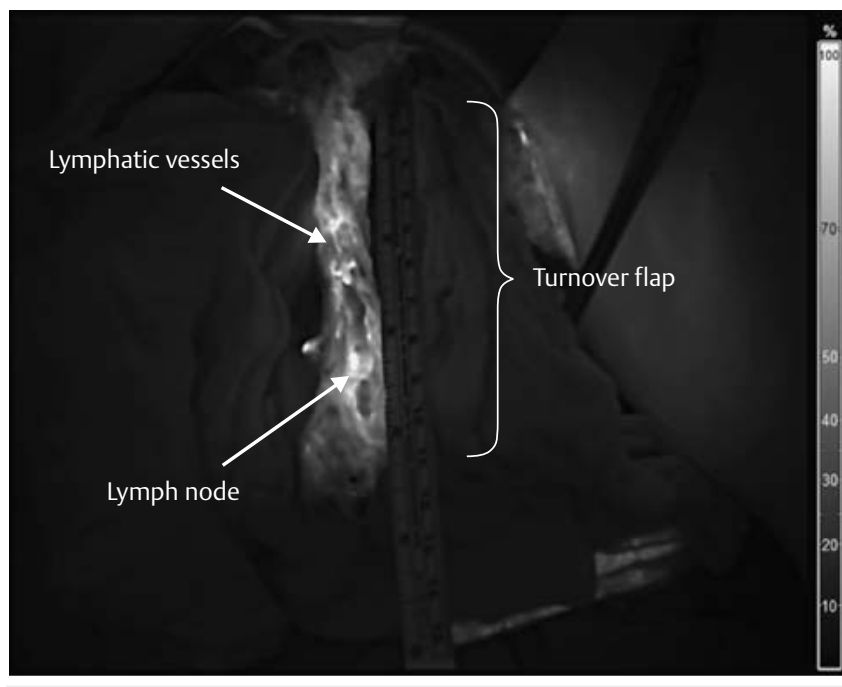

- Fig. 5 Lymphatic perfusion after preoperative injection of indocyanine green using an infrared camera.

lymphatic vessels [18]. Vascularized lymph node transplantation (VLNT) is another microsurgical technique [17]. The most common donor sites are the contralateral axilla and the inguinal nodal basin. Few studies have tried to implement novel donor sites which have yet to be established, such as the submental, greater omentum or epiploic nodal basin [19-21]. In this regard, longterm outcomes for VLNT are lacking. Furthermore, lymph node transplantation and lymphatic venous anastomosis are complex procedures with a steep learning curve. They require not only microsurgical skills but also knowledge in lymphology and the ability to use the appropriate imaging tools [15]. Donor site morbidity is reported as uncommon, but can lead to severe complications and additionally reduces quality of life [22-24].

The procedure illustrated in this paper is easy to learn and does not require extensive microsurgical skills. The multimodal concept of the turnover flap, together with scar tissue excision as well as re-augmentation of the axilla using vascularized transposition of lymph nodes and adipose tissue from the thoracic wall, is an effective therapeutic option that promises to be successful.

We hypothesize that, in breast cancer patients, excision of axillary tissue resulting in scar tissue and volume reduction leads to kinking and obstruction of the lymphatic vessels with secondary blockage of axillary lymphatic drainage. It can be compared to kinking of a straw, where no fluid can pass. By re-augmenting this space with perfused fat tissue combined with lymphatic tissue from the lateral thoracic wall, lymphatic drainage can be restored.

From our experience lymph node transplantation failures can result due to insufficient dissection of scar tissue and opening of the axillary space. Again, kinking of the lymphatic vessels as a result of recurrent scar tissue may reduce lymphatic flow.

\section{Limitations}

This is a retrospective analysis. The number of patients is limited. The hypothesis that axillary scar tissue in patients with lymphedema needs to be removed in full and combined with a re-augment- 
ing turnover flap is based on observations and experience with more than 2000 breast reconstructions. A prospective, randomized trial conducted under standardized conditions is needed to increase the evidence for our observations. Another question is whether this procedure would be useful in patients after breastconserving therapy and lymphedema who do not undergo breast reconstruction. These patients might also benefit from the excision of scar tissue combined with a local transposition turnover flap. Thus, more prospective clinical trials are needed.

The data suggest that this surgical technique would simplify the treatment options of lymphedema of the upper extremities. The postoperative results of the turnover flap available thus far suggest that this technique does not require highly specialized microsurgical training and is therefore appropriate for a wide range of breast surgeons. In addition, this new procedure largely avoids iatrogenic co-morbidities at the donor site.

\section{Conclusion}

Complete removal of the interfering axillary scar tissue after breast cancer treatment and re-augmentation of the axilla with a turnover flap results in a reduction in ipsilateral lymphedema, a decrease in pain, and an improvement in quality of life. We interpret this effect as a result of the physiological re-alignment of the lymphatic vessels combined with a lymph node-containing local transposition flap. Therefore, turnover flap surgery could be an effective alternative to standard lymph node transplantation.

\section{Conflict of Interest}

The authors declare that they have no conflict of interest.

\section{References}

[1] Zou L, Liu FH, Shen PP et al. The incidence and risk factors of related lymphedema for breast cancer survivors post-operation: a 2-year follow-up prospective cohort study. Breast Cancer 2018; 25: 309-314. doi:10.1007/s12282-018-0830-3

[2] DiSipio T, Rye S, Newman B et al. Incidence of unilateral arm lymphoedema after breast cancer: a systematic review and meta-analysis. Lancet Oncol 2013; 14: 500-515. doi:10.1016/S1470-2045(13)70076-7

[3] Taghian NR, Miller CL, Jammallo LS et al. Lymphedema following breast cancer treatment and impact on quality of life: a review. Crit Rev Oncol Hematol 2014; 92: 227-234. doi:10.1016/j.critrevonc.2014.06.004

[4] McLaughlin SA, Staley AC, Vicini F et al. Considerations for clinicians in the diagnosis, prevention, and treatment of breast cancer-related lymphedema: recommendations from a multidisciplinary expert ASBrS panel Part 1: definitions, assessments, education, and future directions. Ann Surg Oncol 2017; 24: 2818-2826. doi:10.1245/s10434-017-5982-4

[5] Tsai RJ, Dennis LK, Lynch CF et al. Lymphedema following breast cancer: The importance of surgical methods and obesity. Front Womens Health 2018. doi:10.15761/FWH.1000144

[6] Rockson SG, Rivera KK. Estimating the population burden of lymphedema. Ann N Y Acad Sci 2008; 1131: 147-154. doi:10.1196/annals.1413.014

[7] Hayes S, Cornish B, Newman B. Comparison of methods to diagnose lymphoedema among breast cancer survivors: 6-month follow-up. Breast Cancer Res Treat 2005; 89: 221-226. doi:10.1007/s10549-004$2045-x$
[8] Vieira RA, da Costa AM, de Souza JL et al. Risk factors for arm lymphedema in a cohort of breast cancer patients followed up for 10 years. Breast Care (Basel) 2016; 11: 45-50. doi:10.1159/000442489

[9] Wetzig N, Gill PG, Espinoza D et al. Sentinel-lymph-node-based management or routine axillary clearance? Five-year outcomes of the RACS Sentinel Node Biopsy Versus Axillary Clearance (SNAC) 1 trial: assessment and incidence of true lymphedema. Ann Surg Oncol 2017; 24: 10641070. doi:10.1245/s10434-016-5669-2

[10] Baumeister RG, Seifert J, Wiebecke B et al. Experimental basis and first application of clinical lymph vessel transplantation of secondary lymphedema. World J Surg 1981; 5: 401-407. doi:10.1007/BF01658013

[11] Becker C, Assouad J, Riquet M et al. Postmastectomy lymphedema: longterm results following microsurgical lymph node transplantation. Ann Surg 2006; 243: 313-315. doi:10.1097/01.sla.0000201258.10304.16

[12] Arbeitsgemeinschaft der Wissenschaftlichen Medizinischen Fachgesellschaften e.V. (AWMF). S2k Leitlinie Diagnostik und Therapie der Lymphödeme (Mai 2017). Online: https://www.awmf.org/uploads/tx_ szleitlinien/058-001I_S2k_Diagnostik_und_Therapie_der_Lymphoedeme _2017-05.pdf; last access: 01.02.2019

[13] Keeley V, Crooks S, Locke J et al. A quality of life measure for limb lymphoedema (LYMQOL). J Lymphoedema 2010; 5: 26-37. doi:10.1177/ 0268355515586312

[14] McLaughlin SA, DeSnyder SM, Klimberg S et al. Considerations for clinicians in the diagnosis, prevention, and treatment of breast cancer-related lymphedema: recommendations from an expert panel - Part 2: preventive and therapeutic options. Ann Surg Oncol 2017; 24: 28272835. doi:10.1245/s10434-017-5964-6

[15] International Society of Lymphology. Diagnosis and Treatment of Peripheral Lymphedema (2016). Online: https://www.internationalsocietyoflymphology.org/wp-content/uploads/2017/12/20106-35060-1-PB. pdf; last access: 01.02.2019

[16] Baumeister RG, Mayo W, Notohamiprodjo M et al. Microsurgical lymphatic vessel transplantation. J Reconstr Microsurg 2016; 32: 34-41. doi:10.1055/s-0035-1554934

[17] Becker C. Autologous lymph node transfers. J Reconstr Microsurg 2016; 32: 28-33. doi:10.1055/s-0035-1563393

[18] Maclellan RA, Greene AK. Lymphedema. Semin Pediatr Surg 2014; 23 : 191-197. doi:10.1053/j.sempedsurg.2014.07.004

[19] Ho OA, Lin CY, Pappalardo M et al. Comparisons of Submental and Groin Vascularized Lymph Node Flaps Transfer for Breast Cancer-Related Lymphedema. Plast Reconstr Surg Glob Open 2018; 6: e1923. doi:10.1097/GOX.0000000000001923

[20] Chu YY, Allen R] jr., Wu T] et al. Greater Omental Lymph Node Flap for Upper Limb Lymphedema with Lymph Nodes-depleted Patient. Plast Reconstr Surg Glob Open 2017; 5: e1288. doi:10.1097/ GOX.0000000000001288

[21] Ciudad P, Manrique OJ, Date S et al. Double gastroepiploic vascularized lymph node tranfers to middle and distal limb for the treatment of lymphedema. Microsurgery 2017; 37: 771-779. doi:10.1002/micr. 30168

[22] Demiri E, Dionyssiou D, Tsimponis A et al. Donor-Site Lymphedema Following Lymph Node Transfer for Breast Cancer-Related Lymphedema: A Systematic Review of the Literature. Lymphat Res Biol 2018; 16: 2-8. doi:10.1089/Irb.2017.0043

[23] Vignes S, Blanchard M, Yannoutsos A et al. Complications of Autologous Lymph-node Transplantation for Limb Lymphoedema. Eur J Vasc Endovasc Surg 2013; 45: 516-520. doi:10.1016/j.ejvs.2012.11.026

[24] Pappalardo M, Patel K, Cheng MH. Vascularized lymph node transfer for treatment of extremity lymphedema: an overview of current controversies regarding donor sites, recipient sites and outcomes. J Surg Oncol 2018; 117: 1420-1431. doi:10.1002/jso.25034 